\title{
POLITYKA ZRÓWNOWAŻONEGO ROZWOJU TRANSPORTU MIEJSKIEGO W KRAJACH WSCHODZĄCYCH NA PRZYKLADZIE STOLICY MEKSYKU
}

\begin{abstract}
Streszczenie. Negatywne efekty zewnętrzne transportu stanowią bolączkę współczesnych miast, niekorzystnie oddziałując na procesy rozwoju społeczno-gospodarczego. Problemy te są widoczne nie tylko w krajach wysoko czy średnio rozwiniętych - w ogromnym stopniu borykają się z nimi wielomilionowe i wielkopowierzchniowe metropolie, które z kolei są charakterystyczne głównie dla krajów wschodzących, jak np. Chiny, Indie, Brazylia czy Meksyk. Celem artykułu jest przedstawienie wybranych aspektów polityki zrównoważonego rozwoju transportu w stolicy jednego z tych krajów - Meksyku. Autorka starała się również odpowiedzieć na pytanie, w jaki sposób specyficzne uwarunkowania lokalne o różnym charakterze determinują dobór narzędzi zrównoważonego rozwoju transportu. W opracowaniu wykorzystano dokumenty źródłowe dotyczące zrównoważonego transportu w Meksyku, w tym raporty i dane statystyczne Banku Światowego.

Slowa kluczowe: negatywne efekty zewnętrzne transportu, polityka zrównoważonego rozwoju transportu miejskiego, Meksyk.
\end{abstract}

\section{WPROWADZENIE}

Transport stanowi nieodłączny element życia ludzkiego, zarówno na poziomie jednostek, jak i całych społeczeństw. Niemal każda sfera działalności ludzkiej wymaga przemieszczania się osób i towarów, bez którego zasadniczo niemożliwy byłby rozwój społeczno-gospodarczy. Współcześnie jednak dobrodziejstwom, jakie niosą ze sobą rozwinięte systemy transportowe, przeciwstawiane są nasilające się niekorzystne zjawiska wynikające z działalności transportowej. Wiążą się one nie tylko $\mathrm{z}$ coraz większą mobilnością ludzi oraz rosnącym wolumenem przewożonych dóbr, lecz także z coraz większą popularnością transportu drogowego, najczęściej wypierającego pozostałe sposoby przewozu osób i towarów, uznawane za bardziej przyjazne człowiekowi i środowisku, takie jak kolej, żegluga śródlądowa, transport publiczny czy przemieszczanie się za pomocą zwykłego roweru lub po prostu chodzenie na piechotę. Ze względu na swą specyfikę negatywne efekty zewnętrzne transportu najczęściej mają charakter lokalny i wywo-

* Uniwersytet Opolski, Wydział Ekonomiczny, Katedra Geografii Ekonomicznej i Gospodarki Przestrzennej. 
łują niekorzystne skutki na tym obszarze, na którym powstają ${ }^{1}$ To sprawia, że w największym stopniu borykają się z nimi ośrodki miejskie, w których występuje przeważnie duże zagęszczenie ludności, a także ma miejsce różnego rodzaju aktywność społeczna i gospodarcza, pociągająca za sobą duży - i wciąż rosnący w miarę rozwoju - popyt na transport. Problemy te sprawiają, iż transport miejski stanowi jeden z obszarów, które wymagają intensywnych działań na rzecz osiągnięcia założeń zrównoważonego rozwoju. Widoczne to jest zarówno w krajach rozwiniętych, jak i rozwijających się, gdzie dynamika wzrostu gospodarczego, a także przemiany społeczne związane ze wzrostem dobrobytu i zmianami stylu życia odzwierciedlają się w wyzwaniach dotyczących transportu.

Celem artykułu jest przedstawienie wybranych aspektów polityki zrównoważonego rozwoju w stolicy jednego z krajów wschodzących - Meksyku. Autorka starała się również odpowiedzieć na pytanie, w jaki sposób specyficzne uwarunkowania lokalne o różnym charakterze determinują dobór narzędzi zrównoważonego rozwoju transportu. W pierwszym rzędzie przedstawiono znaczenie transportu dla rozwoju obszarów miejskich, dalej skrótową charakterystykę Meksyku jako kraju wschodzącego, a następnie zasygnalizowano wyzwania, w obliczu jakich stoją meksykańskie metropolie w budowaniu polityki zrównoważonego rozwoju transportu. Omówiono sukcesy stolicy Meksyku jako miasta, które otrzymało w 2013 r. Nagrodę Zrównoważonego Transportu w kontekście zaprezentowanych uprzednio uwarunkowań. W opracowaniu wykorzystano dokumenty źródłowe dotyczące zrównoważonego transportu w Meksyku, w tym raporty i dane statystyczne Banku Światowego.

\section{ZNACZENIE EFEKTÓW ZEWNĘTRZNYCH TRANSPORTU DLA FUNKCJONOWANIA OBSZARÓW MIEJSKICH}

Jak zaznaczono na początku, transport pełni niebagatelną rolę z punktu widzenia rozwoju społeczno-gospodarczego, co jest widoczne również na poziomie miast. Systemy transportowe można tu porównać do krwioobiegu, warunkującego efektywność przepływu dóbr i osób, a zatem również żywotność ośrodków miejskich oraz możliwości niezakłóconego przebiegu procesów społecznych i ekonomicznych. Korzyści płynące z wydajnych systemów transportowych określane są mianem pozytywnych efektów zewnętrznych ${ }^{2}$. W odniesieniu do obszarów zurba-

${ }^{1}$ Poza emisją gazów cieplarnianych wskutek spalania paliw, co przyczynia się do zmian klimatycznych na poziomie globalnym.

${ }^{2}$ W najbardziej ogólnym rozumieniu efekty zewnętrzne transportu można określić jako takie skutki działalności transportowej, które są ponoszone przez osoby trzecie, niezaangażowane w tę działalność. W tym kontekście można mówić o pozytywnych efektach transportu, które odnoszą się do korzyści, jakie czerpie społeczeństwo bądź wybrane jednostki z procesów transportowych, w których nie uczestniczą, ale również o negatywnych efektach zewnętrznych, gdzie społeczeństwo bądź niektórzy jego członkowie ponoszą koszty z tytułu przewozów, które ich w ogóle nie dotyczą. 
nizowanych można tu wskazać na możliwość różnorodnej lokalizacji aktywności ekonomicznej (Smith 1776), determinowanej jednak istnieniem odpowiedniej infrastruktury transportowej. Umożliwia ona np. przedsiębiorstwom produkcyjnym zaopatrzenie w surowce, dojazd osób do pracy czy też procesy dystrybucji towarów, co wiąże się z zapewnianiem przez transport zwiększonej mobilności czynników produkcji. O ile w wymiarze regionalnym czy krajowym mówi się o korzyściach zewnętrznych transportu, np. w postaci możliwości ekspansji rynków, korzyści skali oraz obniżania cen i większej dostępności produktów czy usług (zob. m.in. Krugman 1998; Rydzkowski, Wojewódzka-Król red. 2007: 1-4; Rodrigue, Notteboom 2014; Wachs 2011), o tyle na poziomie miast można to sprowadzić do rozwoju istniejących przedsiębiorstw, podnoszących poziom produkcji i oferujących większą liczbę miejsc pracy czy odprowadzających wyższe podatki, jak też do napływu inwestorów zagranicznych, którzy (przynajmniej w krótkim okresie) przyczyniają się do ożywienia gospodarczego miast i regionów.

$\mathrm{W}$ ogólnym rozrachunku wydajny system transportowy stanowi jeden z czynników warunkujących konkurencyjność miast i regionów, zarówno w kontekście czysto ekonomicznym, jak i społecznym. System transportowy decyduje bowiem najczęściej o możliwości dotarcia do miejsca pracy, przy czym istotne znaczenie ma to, że jego wydajność wpływa na wzrost zasięgu rynku pracy (np. możliwość znalezienia zatrudnienia w dużej odległości od miejsca zamieszkania). Tym samym transport sprzyja redukcji bezrobocia i przyczynia się do wzrostu zamożności społeczeństwa i/lub ograniczenia ubóstwa. Ponadto dostępność różnego rodzaju instytucji, obiektów i usług społecznych - z zakresu np. edukacji, służby zdrowia, administracji, kultury, sportu i rekreacji - zależy również od efektywności transportu, wpływając bezpośrednio na jakość życia, a jednocześnie na większe możliwości włączenia społecznego. Nawet możliwość zakupienia w placówkach handlowych różnego asortymentu dóbr jest warunkowana przez efektywność transportu. Ze wspomnianych powodów sektor ten oddziałuje na kształtowanie się kapitału ludzkiego i społecznego, co na poziomie miast decyduje m.in. o ich przewadze konkurencyjnej oraz atrakcyjności dla obecnych i potencjalnych mieszkańców. Co więcej, znaczenie transportu uwidacznia się również w skuteczności działań służb ratowniczych, bezpieczeństwa, porządkowych i czystości, bez których miasta nie mogłyby funkcjonować w sposób prawidłowy (zob. m.in. World Bank 1999: 4-22; Mathew, Krishna Rao 2006: 3.1-3.5). Można zatem stwierdzić, iż transport jest czynnikiem sprzyjającym rozwojowi miast oraz spajającym miasta z punktu widzenia przestrzennego, społecznego i ekonomicznego.

Oczywiście oprócz pozytywnych efektów zewnętrznych transportu występują też efekty negatywne, nasilające się zwłaszcza wówczas, gdy za dynamicznym rozwojem w sferze gospodarczej i społecznej - wraz z towarzyszącymi mu zmianami stylu życia, mobilnością i wzrostem aktywności ekonomicznej - nie nadążają przeobrażenia w polityce transportowej oraz przekształcenia systemów transportowych miast. Najczęściej wskazywane w literaturze przedmiotu (zob. 
m.in. IWW, INFRAS 2000, 2004; European Commission 2008) koszty zewnętrzne obejmują kongestię (potocznie zwaną „korkami ulicznymi”), wypadki, zanieczyszczenie powietrza, wody i gleby, hałas i wibracje, nadmierną zajętość terenu przez infrastrukturę i środki transportu, nadmierne zużycie energii czy „psucie” estetyki krajobrazu. Abstrahując od szczegółowych właściwości oraz skutków poszczególnych kategorii efektów zewnętrznych, można stwierdzić, iż przejawiają się one poprzez uciążliwości w sferze społecznej i ekonomicznej, obniżając zarówno jakość życia w miastach, jak i pogarszając warunki prowadzenia działalności gospodarczej. Negatywne efekty zewnętrzne transportu bardzo często powstają nawet w systemach transportowych rozwiniętych pod względem przestrzennym $\mathrm{i}$ infrastrukturalnym, co wiąże się z dużym udziałem transportu drogowego w przewozach, a ich konsekwencje (zwłaszcza kongestii) mogą ograniczać efekty pozytywne. $Z$ tego względu jednym $z$ głównych działań w ramach polityki zrównoważonego rozwoju transportu miejskiego praktycznie na całym świecie jest dążenie do ograniczenia motoryzacji indywidualnej, a także drogowych przewozów ładunków na obszarach zurbanizowanych.

\section{ROZWÓJ SPOŁECZNO-GOSPODARCZY I URBANIZACJA W MEKSYKU A WYZWANIA TRANSPORTU MIEJSKIEGO}

Meksyk uznawany jest za jeden z największych rynków, a jednocześnie za jedno z najdynamiczniej rozwijających się państw. Systematycznie postępujący rozwój społeczno-gospodarczy przesądza o zaliczaniu go do tzw. krajów (rynków) wschodzących ${ }^{3}$. Chociaż w przeciągu ostatnich kilku lat Meksyk doznał spowolnienia gospodarczego, nadal jest on drugą największą gospodarką w Ameryce Łacińskiej i jedną z największych na świecie. Od czasu wejścia w życie Północnoamerykańskiej Strefy Wolnego Handlu (ang. North American Free Trade Agreement, NAFTA) w 1994 r., kraj ten odnotowal ponad 40\% wzrost PKB na jednego mieszkańca, a w przeciągu ostatniego półwiecza zredukowano odsetek ludności żyjącej w ubóstwie z 80\% do 47\% (Taylor 2012). Pomimo wewnętrznych nierówności oraz różnic typowych dla krajów rozwijających się, gdzie ubóstwo kontrastuje zarówno z coraz liczniejszą klasą średnią, jak i klasą nowobogacką; zacofane obszary wiejskie - z wielkimi metropoliami, a tradycyjny przemysł - z inwestycjami w przodujących technologiach, postęp społeczny i ekonomiczny znajduje swoje odzwierciedlenie w natężeniu procesów transportowych oraz trendach rozwoju transportu.

${ }^{3}$ Do krajów (rynków) wschodzących zalicza się państwa cechujące się właśnie szybkim tempem wzrostu gospodarczego, który mierzony jest za pomocą wybranych wskaźników ekonomicznych (zob. MSCI 2014a, 2014b). 


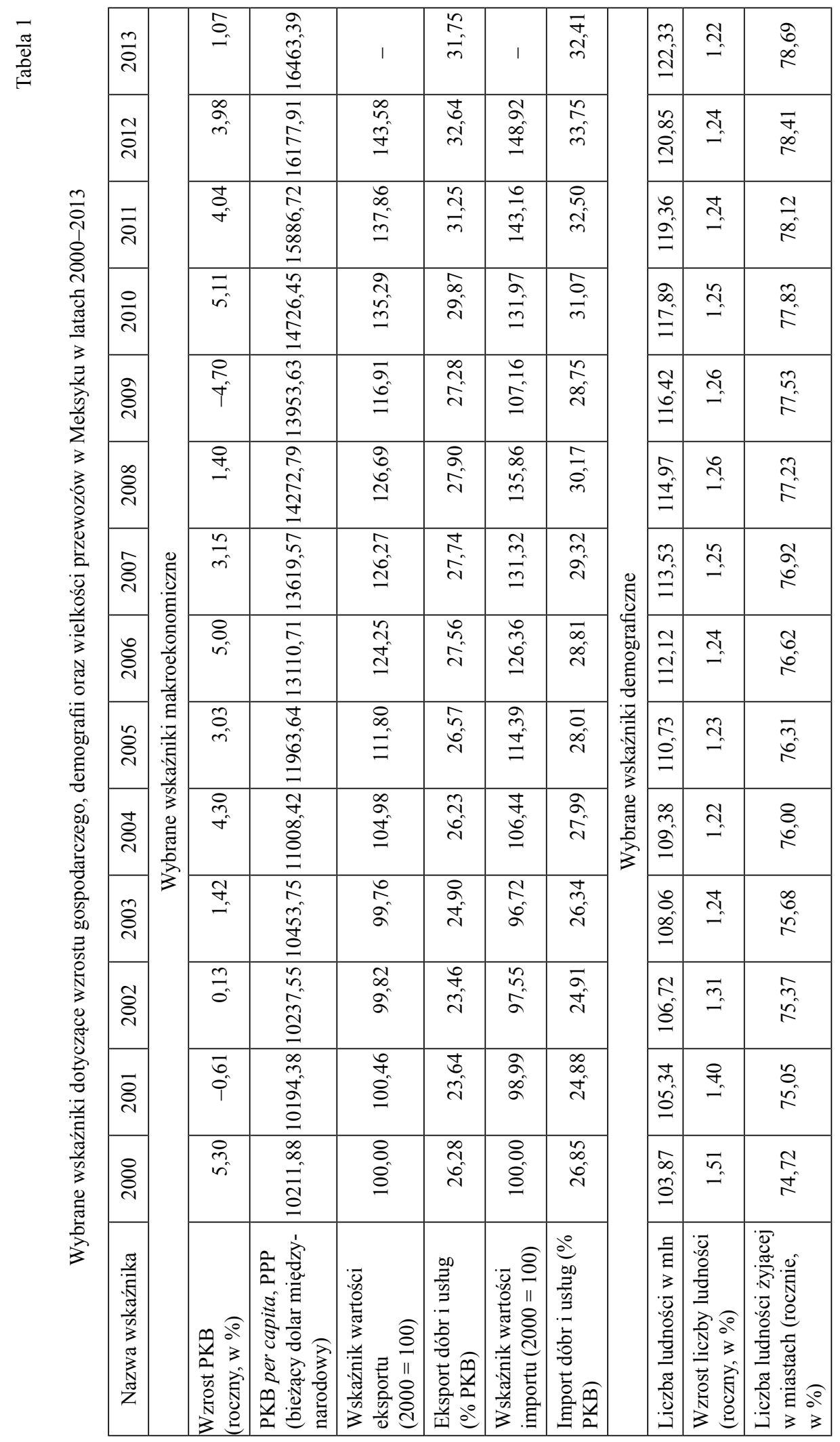




\begin{tabular}{|c|c|c|c|c|c|c|c|c|c|c|c|}
\hline$\stackrel{m}{\stackrel{\sim}{c}}$ & $\begin{array}{l}\infty \\
\sim \\
\sim\end{array}$ & $\underset{⿱}{\stackrel{+}{d}}$ & $\frac{\infty}{\sigma^{\circ}}$ & & 1 & 1 & $\begin{array}{l}\bar{\sigma} \\
\infty \\
\infty\end{array}$ & $\begin{array}{l}\vec{\infty} \\
\infty \\
\infty \\
m\end{array}$ & 1 & 1 & 1 \\
\hline 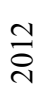 & $\begin{array}{l}\vec{\sigma} \\
\text { i }\end{array}$ & $\underset{\vec{N}}{\vec{N}}$ & $\frac{0}{\sigma_{0}^{\circ}}$ & & I & 1 & $\begin{array}{l}2 \\
\hat{\infty} \\
\hat{2}\end{array}$ & $\begin{array}{l}\bar{\sigma} \\
\text { nิ }\end{array}$ & $\frac{a}{a}$ & $\begin{array}{l}\hat{f} \\
\hat{\sigma}\end{array}$ & $\underset{\sim}{\stackrel{\sim}{*}}$ \\
\hline$\overline{\vec{d}}$ & $\begin{array}{l}\text { ర్ } \\
\text { i }\end{array}$ & $\stackrel{\infty}{\stackrel{\infty}{\sim}}$ & $\begin{array}{l}\text { s. } \\
\text { s. } \\
\text { n. }\end{array}$ & & 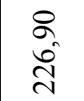 & $\begin{array}{l}8 \\
i \\
i \\
\dot{y}\end{array}$ & $\begin{array}{l}\mathbb{8} \\
\underset{\mathbb{N}}{*}\end{array}$ & $\begin{array}{l}\text { in } \\
\text { ڤิ }\end{array}$ & $\frac{a}{g}$ & $\underset{0}{\stackrel{f}{J}}$ & $\begin{array}{l}\infty \\
\stackrel{\infty}{+}\end{array}$ \\
\hline$\stackrel{\circ}{\circ}$ & $\begin{array}{l}\hat{\sigma} \\
\text { i }\end{array}$ & $\stackrel{\vec{\sigma}}{\vec{N}}$ & ڤू & & $\begin{array}{l}\text { ते } \\
\text { ֻे }\end{array}$ & $\begin{array}{l}m \\
o \\
\tilde{n} \\
\tilde{\sigma}\end{array}$ & 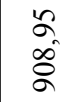 & $\hat{\widehat{n}}$ & 1 & $\frac{\infty}{=}$ & $\begin{array}{l}\hat{b} \\
\text { mi }\end{array}$ \\
\hline ڤे̀े & $\begin{array}{l}n \\
i \\
i\end{array}$ & 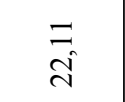 & $\begin{array}{l}\stackrel{\text { a }}{n} \\
\text { mे }\end{array}$ & & $\begin{array}{l}\stackrel{8}{0} \\
\stackrel{\vec{N}}{=}\end{array}$ & 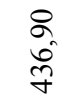 & $\begin{array}{l}8 \\
0 \\
\stackrel{ \pm}{\nabla}\end{array}$ & $\stackrel{n}{n}$ & 1 & $\frac{\infty}{=}$ & $\begin{array}{l}\infty \\
\infty \\
i\end{array}$ \\
\hline $\begin{array}{l}\infty \\
\stackrel{\leftrightarrow}{0}\end{array}$ & $\begin{array}{l}\sqrt{6} \\
i\end{array}$ & $\begin{array}{l}\text { i } \\
\text { ה }\end{array}$ & $\begin{array}{l}\vec{\infty} \\
n \\
m\end{array}$ & & 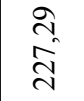 & $\begin{array}{c}\infty \\
\hat{\sigma} \\
\hat{\sigma}\end{array}$ & $\begin{array}{l}\text { शे } \\
\text { ô } \\
\text { क }\end{array}$ & $\begin{array}{l}\infty \\
\infty \\
\infty\end{array}$ & $\stackrel{ \pm}{=}$ & $\begin{array}{l}+ \\
0 \\
0 \\
0\end{array}$ & $\vec{n}$ \\
\hline हे & $\begin{array}{l}\sqrt{2} \\
i\end{array}$ & $\begin{array}{l}\stackrel{0}{0} \\
\text { î }\end{array}$ & $\stackrel{\infty}{\stackrel{\infty}{n}}$ & 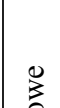 & $\begin{array}{l}\text { ले } \\
\text { तิ } \\
\text { ते }\end{array}$ & 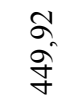 & $\begin{array}{l}\stackrel{+}{m} \\
\text { i } \\
\infty\end{array}$ & $\stackrel{\check{n}}{\hat{\imath}}$ & $\begin{array}{l}8 \\
\approx \\
\approx\end{array}$ & $\begin{array}{l}\text { I } \\
\stackrel{\infty}{0} \\
0 \\
0\end{array}$ & $\stackrel{0}{\because}$ \\
\hline ஓ̊ & $\begin{array}{l}\sqrt{6} \\
i\end{array}$ & $\begin{array}{l}\text { d } \\
\text { i }\end{array}$ & $\vec{n}$ & $\begin{array}{l}\overrightarrow{0} \\
\text { Dे } \\
\text { E्ञ } \\
\text { ज्ञ }\end{array}$ & $\begin{array}{l}\text { ले } \\
\text { ळें }\end{array}$ & $\begin{array}{l}8 \\
\stackrel{m}{+}\end{array}$ & 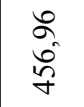 & 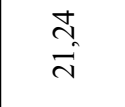 & $\begin{array}{l}\text { ले } \\
\text { ثं }\end{array}$ & $\begin{array}{l}0 \\
0 \\
0 \\
0\end{array}$ & $\begin{array}{l}\infty \\
0 \\
i\end{array}$ \\
\hline ¿̊̀ & $\begin{array}{l}\text { Jo } \\
\text { i }\end{array}$ & $\begin{array}{l}\infty \\
\text { ते }\end{array}$ & $\begin{array}{l}n \\
\cdots \\
n\end{array}$ & 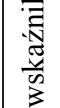 & $\begin{array}{l}\text { ָ̃ } \\
\text { ்ָ }\end{array}$ & $\begin{array}{l}\text { ડ̃ } \\
\text { สิ }\end{array}$ & $\begin{array}{l}\stackrel{m}{+} \\
\stackrel{8}{8}\end{array}$ & $\begin{array}{l}\infty \\
\dot{\vec{v}}\end{array}$ & $\begin{array}{l}\text { ले } \\
\text { ث̂ }\end{array}$ & $\stackrel{0}{0}$ & $\frac{\Delta}{i}$ \\
\hline 弚 & $\begin{array}{l}\hat{b} \\
i\end{array}$ & $\begin{array}{l}\text { बे } \\
\text { ते }\end{array}$ & $\begin{array}{l}\hat{n} \\
n \\
n\end{array}$ & 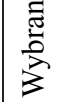 & $\begin{array}{l}\infty \\
\infty \\
2\end{array}$ & $\begin{array}{l}8 \\
\stackrel{8}{7}\end{array}$ & $\begin{array}{l}\hat{\sigma} \\
\text { dे }\end{array}$ & 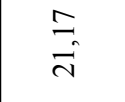 & 1 & 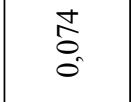 & 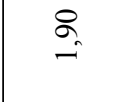 \\
\hline ஜ̊̊ి & $\begin{array}{l}0 \\
\stackrel{0}{0} \\
i\end{array}$ & $\frac{0}{\sqrt[n]{v}}$ & $\begin{array}{l}n \\
n \\
n\end{array}$ & & \begin{tabular}{l} 
તે \\
\multirow{2}{\approx}{}
\end{tabular} & \& & $\begin{array}{l}8 \\
8 \\
\text { ஜn } \\
\text { ñ }\end{array}$ & $\begin{array}{l}\text { : } \\
\stackrel{\text { ¿े }}{ }\end{array}$ & 1 & \begin{tabular}{l}
$\infty$ \\
\multirow{0}{0}{} \\
0
\end{tabular} & $\stackrel{\text { oิ }}{-}$ \\
\hline ญे & $\stackrel{m}{i}$ & $\stackrel{n}{\tilde{v}}$ & \begin{tabular}{l}
0 \\
\multirow{2}{*}{} \\
$n$
\end{tabular} & & $\begin{array}{l}8 \\
\text { ๙் }\end{array}$ & $\begin{array}{c}\text { ते } \\
\text { nે }\end{array}$ & $\begin{array}{l}8 \\
\stackrel{8}{f}\end{array}$ & $\begin{array}{l}\text { ర్ } \\
2 \\
2\end{array}$ & 1 & $\begin{array}{l}8 \\
\stackrel{0}{0} \\
0\end{array}$ & 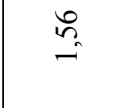 \\
\hline ¿্ণ & $\begin{array}{l}0 \\
\infty \\
i\end{array}$ & $\begin{array}{l}n \\
\tilde{n}\end{array}$ & $\begin{array}{l}\stackrel{g}{2} \\
\tilde{n}\end{array}$ & & 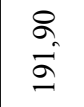 & $\begin{array}{l}m \\
\stackrel{m}{2} \\
\stackrel{\infty}{m}\end{array}$ & $\begin{array}{l}\infty \\
\infty \\
\grave{\lambda}\end{array}$ & $\overrightarrow{\tilde{N}}$ & 1 & $\begin{array}{l}\hat{8} \\
0 \\
0\end{array}$ & $\stackrel{0}{\stackrel{n}{n}}$ \\
\hline ஓ্ণ & $\begin{array}{l}\infty \\
\infty \\
\text { त }\end{array}$ & $\frac{\infty}{\stackrel{n}{v}}$ & $\begin{array}{l}\stackrel{g}{2} \\
\tilde{n}\end{array}$ & & 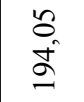 & $\underset{\substack{\stackrel{\infty}{\infty} \\
m}}{\stackrel{2}{n}}$ & $\begin{array}{l}\infty \\
\infty \\
\text { oे }\end{array}$ & $\begin{array}{l}\infty \\
\text { ஸे }\end{array}$ & 1 & $\begin{array}{l}\text { OD } \\
0 \\
0 \\
0\end{array}$ & $\stackrel{\sim}{\sim}$ \\
\hline 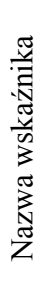 & 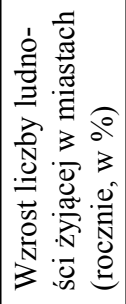 & 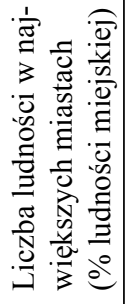 & 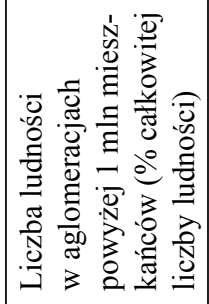 & & 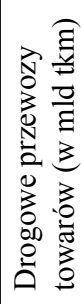 & 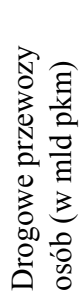 & 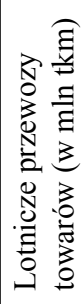 & 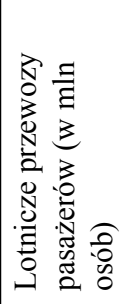 & 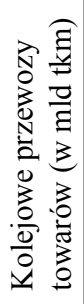 & 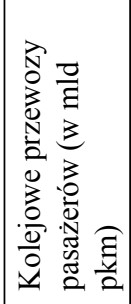 & 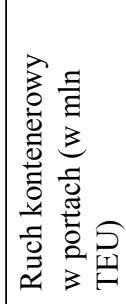 \\
\hline
\end{tabular}


W tab. 1 zaprezentowano wybrane wskaźniki obrazujące wzrost gospodarczy, procesy demograficzne, a zwłaszcza urbanizacyjne, jak również zmiany wielkości przewozów w Meksyku. Chociaż analizowany kraj wschodzący nie może poszczycić się takim tempem wzrostu, jak np. Chiny czy Indie (zob. m.in. World Bank 2014a), jednak należy do krajów odnotowujących najszybszy przyrost PKB na jednego mieszkańca, z dużą dynamiką wzrostu wartości importu i eksportu. Ponadto, trzeba zwrócić uwagę na istotny z punktu widzenia podejmowanej problematyki postępujący proces urbanizacji - obecnie niemal $80 \%$ ludności z ponad 122-milionowej populacji żyje w miastach, w tym więcej niż jedna trzecia w ośrodkach miejskich z ponadmilionową liczbą mieszkańców. Co więcej, w latach 2000-2013 średnioroczny przyrost ludności miejskiej przewyższał około dwukrotnie przyrost naturalny. Nie można pomiąć tutaj faktu, iż procesom tym towarzyszą zmiany wielkości przewozów osób i towarów. W całym kraju nastąpiło zwiększenie liczby przewozów drogowych, przede wszystkim osób, dynamicznie wzrósł też wolumen towarów przewożonych drogą lotniczą, jak też liczba kontenerów obsługiwanych w portach. $Z$ jednej strony powiązać to należy $\mathrm{z}$ rolą transportu w obsłudze gospodarki narodowej oraz handlu zagranicznego. W kontekście problematyki transportu miejskiego należy jednak zaznaczyć, iż miasta i metropolie charakteryzują się specyficznymi systemami transportowymi, a przekształcenia w ich organizacji, funkcjonowaniu oraz zmiany trendów transportowych zachodzą często intensywniej i w nieco odmienny sposób, aniżeli na poziomie gospodarek narodowych.

\section{ZAGROŻENIA ZWIĄZANE Z NIEZRÓWNOWAŻONYM TRANSPORTEM W MIASTACH MEKSYKAŃSKICH}

Jak wskazują współczesne doświadczenia miast, zwłaszcza w krajach rozwijających się (zob. m.in. Signal 2010; World Bank 2014b), dynamiczny rozwój zorientowany przede wszystkim na efekty w sferze gospodarczej, ale też odzwierciedlający się w sferze społecznej, prowadzi z jednej strony do szybkiego wzrostu popytu na transport osób i towarów, a z drugiej - do preferowania transportu drogowego ze względu na jego cechy organizacyjno-eksploatacyjne. Prowadzi to w krótkim okresie do zmian w funkcjonowaniu systemu transportowego, przejawiających się przede wszystkim spadkiem jego wydajności, a także narastaniem kosztów zewnętrznych transportu.

Powyższa „ścieżka zależności” w procesach rozwojowych nie ominęła również miast i metropolii meksykańskich, w których $\mathrm{w}$ ostatnich latach - w różnym natężeniu - nastąpił wzrost negatywnych efektów zewnętrznych transportu. Jeden z głównych problemów stanowi tutaj zanieczyszczenie powietrza generowane przez transport miejski, które w wielu metropoliach w Meksyku uznawane jest za najpoważniejszy problem środowiskowy oraz zagrożenie 
dla zdrowia mieszkańców (World Bank 2009: 25). Istotna staje się negatywna rola transportu indywidualnego, który np. w stolicy Meksyku emituje trzykrotnie więcej tlenku węgla aniżeli transport zbiorowy, niemal dwukrotnie więcej tlenków azotu, ponad 7 razy więcej dwutlenku siarki i pyłów zawieszonych oraz ponad 5 razy więcej dwutlenku węgla (Corporación Andina de Fomento 2010: 66-67). Niemniej znaczącą uciążliwością, przyczyniającą się dodatkowo do powstawania innych negatywnych efektów zewnętrznych transportu, jest kongestia, zwłaszcza w większych ośrodkach metropolitalnych (zob. m.in. World Bank 2009: 2; Rivera et al. 2011: 11, 20, 22). WHO szacuje, że w całym Meksyku rokrocznie ginie w wypadkach drogowych około 16700 osób, w tym głównie młodzi ludzie w przedziale wiekowym 15-29 lat. Podobnie jak w Europie, ponad jedna trzecia ofiar to piesi, rowerzyści oraz motocykliści (WHO 2014: 157). Obszary miejskie są najbardziej narażone na wypadki z uwagi na rozmiary ruchu drogowego. Co więcej, wypadki to piąta główna przyczyna śmierci w Meksyku (World Bank 2009: 24). Coraz bardziej widocznym problemem staje się też wzrastająca konsumpcja energii przez sektor transportu, wynikająca przede wszystkim z coraz większego wykorzystywania samochodów osobowych. Nawet pomimo spowolnienia gospodarczego, w latach 2000-2011 konsumpcja oleju napędowego per capita wzrosła w Meksyku o 22\% (z około 120 do $125 \mathrm{~kg}$ ekwiwalentu na jednego mieszkańca), a benzyny o 30\% (z około 214 do $280 \mathrm{~kg}$ ekwiwalentu na jednego mieszkańca) (World Bank 2014a). Bezpośrednim skutkiem tej sytuacji jest wzrost cen paliw, co w konsekwencji prowadzi do spadku popytu i mniejszych wydatków w innych sferach życia Meksykanów. Ponadto w szybszym tempie wzrasta cena oleju napędowego, co negatywnie oddziałuje na kondycję przewoźników w miejskim transporcie publicznym (zob. Rivera et al. 2011: 5).

Pomimo braku dokładnych danych dotyczących innych kategorii kosztów zewnętrznych, w różnych źródłach wskazuje się też kolejne problemy związane z niezrównoważonym rozwojem transportu w meksykańskich miastach, takie jak np. zajętość terenu, hałas i wibracje itp. (zob. World Bank 2009; Corporación Andina de Fomento 2010). W ogólnym rozrachunku, w meksykańskich miastach negatywne efekty zewnętrzne transportu nie tylko wywołują pochodne negatywne skutki środowiskowe (np. zanieczyszczenie powietrza, niszczenie ekosystemów), społeczne (np. utrata zdrowia wskutek zanieczyszczenia, utrata zdrowia czy życia wskutek wypadków itp.) oraz gospodarcze (np. problemy z punktualnością dostaw czy dojazdem pracowników do pracy). Koszty te, w tym zwłaszcza kongestia, prowadzą do spadku efektywności funkcjonowania miejskich systemów transportowych, co skutkuje ograniczeniem pozytywnych efektów zewnętrznych transportu.

Niekorzystne zjawiska wynikające $\mathrm{z}$ funkcjonowania transportu miejskiego mają w Meksyku klika przyczyn. Dwie z nich zostały już wspomniane powyżej i można je uznać za typowe dla wielu miast na całym świecie. Należą do nich: 
postępująca urbanizacja, wzrost dobrobytu oraz rosnąca popularność transportu drogowego z motoryzacją indywidualną na czele. W latach 1965-2013 odsetek ludności Meksyku zamieszkujący obszary zurbanizowane wzrósł z około 55\% do niemal $79 \%$, zaś odsetek ludności zamieszkujący ponadmilionowe miasta - z ponad $24 \%$ do ponad $36 \%$. Towarzyszy temu rosnący wskaźnik motoryzacji, który w okresie 2000-2011 zwiększył się ze 102 do 195 samochodów osobowych na 1000 mieszkańców (World Bank 2014a). Warto jednak zauważyć, że w rozwiniętych krajach wskaźnik motoryzacji jest ponad dwukrotnie wyższy ${ }^{4}$. Co więcej, o ile w wielu miastach samochody osobowe stanowią około $80 \%$ pojazdów zmotoryzowanych, o tyle przeciętnie wykonuje się nimi około $30 \%$ dziennych podróży (World Bank 2009: 24). Szybki wzrost motoryzacji, głównie w meksykańskich metropoliach, przekłada się jednak na spadek wydajności systemów transportowych.

W odniesieniu do Meksyku relatywnie trudna sytuacja miejskich systemów transportowych stanowi jednak pochodną kilku innych czynników, specyficznych dla analizowanego kraju i wynikających z różnorodnych uwarunkowań. W pierwszym rzędzie należy wskazać nieefektywną organizację transportu zbiorowego oraz przewagę tzw. zbiorowej taksówki (w Meksyku nazywanej peseros). Zgodnie z ukształtowanym historycznie, dominującym na meksykańskich obszarach zurbanizowanych modelem transportu zbiorowego, na rynku konkuruje ze sobą wielu operatorów, wśród których bardzo liczni dysponują tylko jednym pojazdem (najczęściej wysłużonym minibusem), bez ustalonych tras oraz rozkładu jazdy (zob. m.in. Roschlau 1981; World Bank 2009: 24). W rezultacie transport publiczny nie tylko funkcjonuje $\mathrm{w}$ sposób zawodny $\mathrm{z}$ punktu widzenia pasażera, a co najmniej wielce niepewny, zwłaszcza pod względem realizacji podróży do/z pracy czy szkoły, lecz także generuje wiele zanieczyszczeń, zaś w związku z częstą nadpodażą - również kongestię (World Bank 2009: 24). Na brak efektywności transportu publicznego składają się tutaj: niemożność wprowadzenia wydajnego systemu organizacyjnego zapewniającego przewozy wysokiej jakości, rozproszony rynek przewoźników i operacji przewozowych, co utrudnia kontrolę usług transportowych, niewydajne wykorzystywanie minibusów oraz struktura wiekowa pojazdów powodująca duże zanieczyszczenia, brak zarządzania i koordynacji usług przewoźników, brak integracji fizycznej, operacyjnej, organizacyjnej oraz taryfikacyjnej (World Bank 2009: 24-25). W warunkach szybkiej urbanizacji transport publiczny nie był w stanie sprostać rosnącemu popytowi na transport, zwłaszcza pod względem rosnącej liczby coraz dłuższych i bardziej skomplikowanych tras podróży.

W wielu meksykańskich metropoliach brak koordynacji charakteryzuje nie tylko transport zbiorowy, lecz także sferę instytucjonalną, stanowiąc poważne

${ }^{4}$ Na przykład w 2010 r. w UE-28 wynosił on 487, w UE-15 - 505, a w Polsce w 2012 r. 486 samochodów osobowych na 1000 mieszkańców (Eurostat 2014). 
ograniczenie dla prowadzenia zintegrowanych działań w ramach organizacji transportu miejskiego i miejskich systemów transportowych. Odpowiedzialność za różne sfery rozwoju transportu podzielona jest pomiędzy poziom federalny, stanowy i lokalny (władze miejskie). Co więcej, na każdym z tych poziomów funkcjonuje wiele agencji i instytucji, posiadających różne kompetencje w zakresie np. kreowania przepisów prawnych, planowania rozwoju infrastruktury, finansowania polityki transportowej, planowania przestrzennego czy planowania i zarządzania transportem. W efekcie, na poziomie miast często dochodzi do sytuacji, gdy w opracowywanie polityki transportowej zaangażowanych jest wiele podmiotów instytucjonalnych, posiadających różne kompetencje i interesy, co znacznie utrudnia jej harmonizację, wytyczanie i osiąganie założonych celów. Odnosi się to również do projektów współfinansowanych przez instytucje i organizacje międzynarodowe, jak np. Andyjski Bank Rozwoju czy Bank Światowy. Przeszkodą niejednokrotnie jest też brak odpowiednio wykwalifikowanych i wyszkolonych osób na odpowiednich stanowiskach (zob. World Bank 2009: 5, 25).

Do czynników niekorzystnie oddziałujących na funkcjonalność systemów transportowych należą też kwestie związane $\mathrm{z}$ historycznym zagospodarowywaniem przestrzeni $w$ miastach. $Z$ jednej strony ścisłe centra, powstałe za czasów kolonialnych, cechuje często koncentracja zabudowy, podobnie jak w historycznych centrach miast europejskich. Z drugiej zaś metropolie meksykańskie przeważnie odznaczają się dużą powierzchnią i rozwiniętymi przedmieściami, relatywnie niewielką gęstością zaludnienia oraz największą liczbą miejsc pracy w śródmieściu, co skutkuje dużymi odległościami w codziennych podróżach. Brak oddzielnej infrastruktury dla autobusów sprawia, że z jednej strony zatrzymujące się co chwila pojazdy transportu zbiorowego wstrzymują ruch drogowy, a z drugiej - coraz większa liczba samochodów osobowych spowalnia autobusy. Ponadto ulice miejskie bardzo często nie posiadają wystarczającej przepustowości, nie są też wyposażone w odpowiednie elementy infrastrukturalne, takie jak skoordynowane oświetlenie czy wystarczająca liczba miejsc parkingowych. Dodając do tego brak adekwatnej dbałości o utrzymanie infrastruktury, zagadnienia dotyczące zarządzania popytem i egzekwowania przestrzegania przepisów ruchu drogowego (bądź ich ustanawiania), otrzymujemy obraz niewydajnych miejskich systemów transportowych, gdzie najwięcej przeszkód napotyka transport publiczny wraz z pasażerami (World Bank 2009: 2, 25).

W podsumowaniu rozważań dotyczących zagrożeń związanych z transportem miejskim w Meksyku nie można pominąć kwestii związanych z coraz szybciej rozwijającą się w wielu miastach tzw. „kulturą samochodu”, uznawanego zbyt często za najdogodniejszy środek transportu. Wynika to m.in. z lansowanego na świecie modelu konsumpcyjnego i modelu dobrobytu, gdzie jakość życia utożsamiana jest $\mathrm{z}$ posiadaniem. 


\section{POLITYKA ZRÓWNOWAŻONEGO ROZWOJU TRANSPORTU MIEJSKIEGO W STOLICY MEKSYKU}

Stolica Meksyku to jedna z tych metropolii, w których zagrożenia i uciążliwości wynikające z niezrównoważonego rozwoju transportu były w kraju największe. Kongestia, uniemożliwiająca płynny przejazd pojazdom oraz swobodne przejście pieszym (nie tylko) w centrum, zanieczyszczenie powietrza ${ }^{5}$, wypadki $i$ hałas były charakterystyczne dla miasta jeszcze kilka-kilkanaście lat temu (zob. m.in. Rivera et al. 2011: 9-27). W efekcie obniżała się zarówno jakość życia mieszkańców, jak i atrakcyjność stolicy dla prowadzenia działalności gospodarczej, a to z uwagi na rosnące koszty oraz malejące korzyści zewnętrzne transportu. Nieefektywny system transportowy stał się barierą dla rozwoju miasta, co skłoniło jego włodarzy do podjęcia działań w celu rozwiązania narastających problemów.

Pomimo wcześniejszych prób w tym zakresie, za przełom w zintegrowanych działaniach uznaje się rok 2007, kiedy to rozpoczęto wdrażanie w stolicy Meksyku tzw. „Zielonego Planu”, ukierunkowanego na osiągnięcie wielu celów ekologicznych. Zakłada on implementację do 2022 r. licznych akcji i programów, mających doprowadzić do redukcji zanieczyszczeń i gazów cieplarnianych oraz poprawy kondycji transportu (UN 2010). „Zielony Plan” obejmuje 7 podstawowych obszarów interwencji, z których jeden dotyczy transportu oraz mobilności i koncentruje się na 5 celach głównych: 1) poprawie jakości i dostępności transportu publicznego; 2) zmniejszeniu liczby samochodów osobowych na drogach; 3) promocji niezmotoryzowanych środków transportu; 4) zwiększeniu prędkości przemieszczania się; 5) rozwoju kultury drogowej szanującej pieszych i rowerzystów (ICLEI 2010). Większość z założonych celów miała być zrealizowana do 2012 r., kiedy to w Meksyku nastąpiły ponowne wybory. Obecna władza nie jest zobowiązana do wypełniania planu, ponieważ nie został on uchwalony jako prawnie obowiązujący. Niemniej jednak, szybkie i bezpośrednie rezultaty 5 lat realizacji założeń zaowocowały uhonorowaniem stolicy Meksyku Nagrodą Zrównoważonego Transportu (ang. Sustainable Transport Award) w 2013 r. ${ }^{6}$

Ogólnie rzecz biorąc, struktura przewozów osobowych w stolicy Meksyku nadal może być uznawana za korzystną z uwagi na dominację innych - poza motoryzacją indywidualną - form przemieszczania się. W 2007 r. 20,7\% podróży

${ }^{5}$ Według ekspertów zajmujących się ochroną środowiska, oddychanie powietrzem w stolicy Meksyku przez jeden dzień było równoznaczne z wypaleniem ok. 40 papierosów (ICLEI 2010).

${ }^{6}$ Nagroda Zrównoważonego Rozwoju Transportu nadawana jest przez Instytut Polityki Transportu i Rozwoju (The Institute for Transportation and Development Policy - ITDP) corocznie miastom, które mogą poszczyć się największymi osiągnięciami w tej dziedzinie. Przy podejmowaniu decyzji co do zwycięzcy ITDP wspierany jest przez m.in. przedstawicieli Banku Światowego czy ICLEI's EcoMoblity (zob. ITDP 2014). 
wykonywanych było za pomocą samochodu osobowego, przy czym zauważalny staje się (poza wciąż coraz popularniejszym samochodem) wzrost wykorzystania transportu publicznego i rowerowego przy spadku popytu na wspomniane zbiorowe taxi (Rivera et al. 2011: 17). Do tych sukcesów - z punktu widzenia polityki zrównoważonego transportu - przyczyniło się jednak wiele inicjatyw i akcji w ramach „Zielonego Planu”. Jedną z nich była rozbudowa zainicjowanego na początku obecnego wieku, a powstałego w 2005 r. systemu Bus Rapid Transit o nazwie Metrobus, który ma stanowić alternatywę dla mało efektywnych pod wieloma względami peseros. Wsparcie finansowe zostało udzielone nie tylko przez instytucje federalne i stanowe, lecz także przez Bank Światowy oraz inwestorów prywatnych, a budowę samego systemu uwzględniono w kilku strategiach rozwoju transportu i poprawy jakości powietrza na obszarze metropolitalnym stolicy. W zamierzeniu 800 nowoczesnych, ekologicznych autobusów w ramach systemu Metrobus ma zastąpić ponad 3000 „tradycyjnych” autobusów i mikrobusów, dzięki czemu np. ma się zmniejszyć emisja $\mathrm{CO}_{2}$ o 214000 ton rocznie (Rivera et al. 2011: 34). W 2012 r. w ramach systemu funkcjonowały cztery linie, obejmujące łącznie $95 \mathrm{~km}$, obsługiwane przez 365 pojazdów i przewożące około 750000 pasażerów dziennie (Francke et al. 2012: 18). Ograniczono w ten sposób wiele kosztów zewnętrznych transportu, a dodatkowo zaoferowano mieszkańcom transport publiczny spełniający podstawowe postulaty transportowe, takie jak częstotliwość i pewność kursów, punktualność, komfort podróżowania itp.

Rozbudowa systemu Metrobus to nie jedyne ważne przedsięwzięcie w ramach „Zielonego Planu”. Niezwykle istotną rolę w polityce zrównoważonego rozwoju transportu w stolicy Meksyku odgrywa od 2010 r. przywracanie pieszym i rowerzystom przestrzeni w historycznym centrum. Wyprowadzono ruch drogowy nie tylko z wielu wąskich ulic, lecz także z dużych placów, rozbudowano sieć ścieżek rowerowych, ponadto $\mathrm{w}$ wielu miejscach wprowadzono priorytety dla transportu publicznego i taksówek. W rezultacie podsystem transportowy w centrum stał się przyjazny dla tych użytkowników transportu, którzy korzystają z bardziej ekologicznych sposobów przemieszczania się, a jednocześnie dzięki temu uzyskano efekty pośrednie w postaci bardziej przyjaznej przestrzeni publicznej dla mieszkańców, turystów itp., co wywarło również pozytywny wpływ na handel i usługi (ICLEI 2010, EMBARQ 2014). Działaniom tym towarzyszyła implementacja i rozbudowa systemu wypożyczalni rowerów ECOBICI. Jak szacuje EMBARQ Mexico (2012), dzięki „kampanii rowerowej” 40,3\% użytkowników ECOBICI przestało korzystać z samochodu na krótkie dystanse, co odpowiada około 2065 dniom zaoszczędzonym wskutek uniknięcia „stania w korku” oraz redukcji $\mathrm{CO}_{2}$ o 232 tony. Do końca 2014 r. ECOBICI ma funkcjonować na powierzchni $34 \mathrm{~km}^{2}$ z 444 stacjami i 6200 rowerami, które docelowo mają służyć 20 mln użytkowników (Gizela 2014).

Jak pokazuje doświadczenie, same narzędzia infrastrukturalne nie są w stanie zapewnić pełni efektów w zakresie zrównoważonego rozwoju transportu. $\mathrm{Z}$ tego 
względu w stolicy Meksyku położono nacisk również na akcje edukacyjno-informacyjne oraz promocję zrównoważonego transportu, aby zmienić zachowania komunikacyjne mieszkańców. Już pod koniec lat 80. XX w. zainicjowano akcję „Hoy No Circula” (Dzisiaj nie prowadzę), polegającą na zakazie jazdy samochodem w zależności od ostatniej cyfry w numerze rejestracyjnym w określony dzień tygodnia roboczego. „Zielony Plan” rozszerzył tę akcję również o sobotę. Ponadto, w 2007 r. rozpoczęto realizację edukacyjnego programu „Muevete en Bici” (Wsiadaj na rower), promującego ten ekologiczny środek transportu w połączeniu $\mathrm{z}$ ułatwieniami infrastrukturalnymi oraz priorytetowymi zasadami ruchu dla rowerzystów, zasygnalizowanymi powyżej (ICLEI 2010).

Jak już wspomniano, strategia zawarta w „Zielonym Planie” stanowiła wyraz koordynacji i integracji działań mających doprowadzić do bardziej zrównoważonego rozwoju transportu w stolicy Meksyku. Warto jednak zaznaczyć, że prowadzone są też inne akcje i programy, inicjowane przez instytucje różnych szczebli, czego najlepszym przykładem jest program ukierunkowany na zmianę organizacji zbiorowego taxi, wprowadzony na poziomie federalnym w $2002 \mathrm{r}$. Program zakładał dopłatę dla właścicieli taksówek (mini- i mikrobusów) na zakup nowego pojazdu w zamian za oddanie starego, który następnie był poddawany recyklingowi, a także szkolenie dla taksówkarzy dotyczące zarządzania finansami osobistymi oraz obsługi klienta. Celem programu było ograniczenie emisji zanieczyszczeń i gazów cieplarnianych, poprawa bezpieczeństwa ruchu drogowego, ograniczenie kradzieży pojazdów, a także zapewnienie, że stare pojazdy zostaną odpowiednio wycofane z użytkowania i zutylizowane (Rivera et al. 2011: 34). Ogromnej pomocy miastom meksykańskim, w tym i stolicy, udziela Bank Światowy, nie tylko w zakresie współfinansowania projektów, ale też pod względem instytucjonalnym, badawczym czy wykonawczym, w ramach prowadzonego od 2006 r. i następnie kontynuowanego projektu „Mexico - Sustainable Transport and Air Quality” („Meksyk - Zrównoważony Transport i Jakość Powietrza”) (zob. World Bank 2014c).

\section{PODSUMOWANIE}

Stolica Meksyku to jedno z miast, które dowiodły, iż w relatywnie krótkim okresie można osiągnąć szereg efektów dotyczących zrównoważonego rozwoju transportu. Niemniej jednak przykład ten obrazuje również, że - jak w większości przypadków - działania $\mathrm{w}$ zakresie polityki transportowej podejmowane są dopiero wówczas, gdy eskalacja kosztów zewnętrznych transportu przyczynia się do obniżania dobrobytu społecznego, atrakcyjności ośrodków miejskich, pogarszania warunków prowadzenia działalności gospodarczej itp. Kraje rozwijające się pod wieloma względami mogą korzystać z doświadczeń państw rozwiniętych, 
w których problemy wynikające $\mathrm{z}$ niezrównoważonego transportu miejskiego w wielu przypadkach zostały ograniczone dzięki różnorodnym instrumentom infrastrukturalnym, ekonomiczno-rynkowym, administracyjno-prawnym, technologicznym, edukacyjnym itp.

Należy tutaj jednak zasygnalizować dwie kwestie. Po pierwsze, współcześnie priorytetowe cele rozwojowe koncentrują się na zagadnieniach społeczno-gospodarczych, czego bezpośrednie i pośrednie konsekwencje obrazują niekorzystne zmiany w miejskich systemach transportowych. W tym kontekście pojawiają się pytania, na ile można kontrolować kierunki oraz warunki rozwoju w krajach nieposiadających wystarczającego potencjału instytucjonalnego czy finansowego, a także czy można w jakiś sposób interweniować czy w krótkim okresie wręcz hamować dynamikę procesów rozwojowych w krajach rozwijających się, skoro kraje rozwinięte w niedalekiej przeszłości popełniały te same błędy. Wydaje się, że i tak na poziomie międzynarodowym powstały liczne instytucje i organizacje promujące współpracę, integrację działań i wsparcie państw rozwijających się w zakresie kształtowania zrównoważonego transportu miejskiego.

Po drugie, jak ukazuje przykład Meksyku, kraje rozwijające się posiadają - poza pewnymi „wspólnymi” przyczynami powstawania kosztów zewnętrznych transportu - specyficzne uwarunkowania dotyczące funkcjonowania miejskich systemów transportowych. To z kolei będzie wymuszać dobór specyficznych instrumentów. $Z$ jednej strony mogą one dotyczyć kwestii historycznego ukształtowania, zabudowy i zagospodarowania przestrzennego miast. W Meksyku większość metropolii zajmuje rozległy obszar, z niezbyt skoncentrowaną i wysoką zabudową, a tym samym względnie niewielką gęstością zaludnienia, co wpływa $\mathrm{z}$ jednej strony na ograniczony popyt na transport $\mathrm{w}$ różnych częściach miasta, a z drugiej - na odległość podróży. To może sprawiać, że systemy Bus Rapid Transit będą lepszym rozwiązaniem w niektórych miastach aniżeli np. transport szynowy w postaci metra czy kolei miejskiej, zwłaszcza z uwagi na istniejącą infrastrukturę preferującą transport drogowy. Dodatkowo model transportu zbiorowego oparty na usługach drobnych prywatnych przedsiębiorstw przewozowych sam w sobie przyczyniał się do niewydolności systemów transportowych i kosztów zewnętrznych transportu. Stanowiło to bodziec do wprowadzania zorganizowanego autobusowego transportu publicznego zarządzanego przez jednostki zależne od władz miejskich w wielu miastach Meksyku (zob. Rivera et al. 2011), co np. w krajach europejskich zazwyczaj stanowi oczywistość. Istotną rolę odgrywają także warunki pogodowe. O ile w samej stolicy Meksyku klimat sprzyja korzystaniu z rowerów, o tyle $\mathrm{w}$ wielu miastach i metropoliach meksykańskich upał sprawia, iż nawet budowa infrastruktury i wprowadzanie preferencji w ruchu drogowym dla rowerzystów niekoniecznie przekonają mieszkańców do tego sposobu przemieszczania się ${ }^{7}$. „Kultura samochodu” w Meksyku wynika nie tylko

\footnotetext{
${ }^{7}$ Informacje uzyskane na podstawie prezentacji C.A.L.M.A. Adriana (2014).
} 
z modelu konsumpcji promowanego przez bogate kraje, w tym zwłaszcza Stany Zjednoczone Ameryki, ale też z faktu, iż w mniejszych czy uboższych od stolicy miastach nadal brakuje potencjału instytucjonalnego czy środków finansowych na wdrożenie rozwiązań na rzecz zrównoważonego transportu, dostosowanych do specyficznych warunków lokalnych.

\section{BIBLIOGRAFIA}

C.A.L.M.A. Adriana (2014), Perspectives of Urban Mobility and Logistic for a Sustainable University Transport, presentation, $14^{\text {th }}$ International Conference on Current Issues of Sustainable Development - Sustainable Energy Supply and Sustainable Product Innovation, Opole, Polska, 26-28 June.

Corporación Andina de Fomento (2010), Observatorio de Movilidad Urbana para América Latina, http://www.caf.com/media/4099/caf_omu_jun2010.pdf (dostęp: 29.10.2014).

EMBARQ (2014), New Mobility Law in Mexico City to Catalyze Safe, Sustainable Transport, http://www.embarq.org/news/new-mobility-law-mexico-city-catalyze-safe-sustainable-transport (dostęp: 30.10.2014).

EMBARQ Mexico (2012), ECOBICI GEI Emission Reduction Survey, http://www.sedema.df.gob. $\mathrm{mx} / \mathrm{sedema/index.php/movilidad-sustentable/movilidad-en-bicicleta} \mathrm{(dostęp:} \mathrm{30.10.2014).}$

European Commission (2008), Handbook on Estimation of External Costs in the Transport Sector, Internalisation Measures and Policies for All external Cost of Transport (IMPACT), Delft, European Commission.

Eurostat (2014), Dane statystyczne - liczba samochodów na 1000 mieszkańców, http://appsso.eurostat.ec.europa.eu/nui/show.do?dataset=road_eqs_carhab\&lang=en (dostęp: 29.10.2014).

Francke E., Macías J., Schmid G. (2012), Mobilising Private Investment for Bus Rapid Transit Systems: The Case of Metrobus, Mexico City, CTS EMBARQ Mexico, OECD, http://www.oecd. org/env/cc/Case\%20study\%20Mexico.pdf (dostęp: 30.10.2014).

Gizela M. (2014), Beyond Move in Mexico City: Integrating Sustainable Mobility into the Everyday, „The CityFix”, EMBARQ, http://thecityfix.com/blog/beyond-move-mexico-city-integrating-sustainable-mobility-ecobici-biking-gisela-mendez (dostęp: 30.10.2014).

ICLEI (2010), Mexico City's Green Plan: EcoMobility in motion, ICLEI Case Study 121 Mexico City 2010 final, http://www.ecomobility.org/fileadmin/template/project_templates/ecomobility/files/Publications/CS_Mexico_city.pdf(dostęp: 29.10.2014).

ITDP (2014), Mexico City Takes the 2013 Sustainable Transport Award, https://www.itdp.org/mexico-city-takes-the-2013-sustainable-transport-award (dostęp: 29.10.2014).

IWW Uniwersitaet Karlsruhe, INFRAS (2000), External Costs of Transport. Accident, Environmental and Congestion Costs in Western Europe, Zurich/Karlsruhe, IWW Uniwersitaet Karlsruhe, INFRAS.

IWW Uniwersitaet Karlsruhe, INFRAS (2004), External Costs of Transport - Update Study, Final Report, Zurich/Karlsruhe, IWW Uniwersitaet Karlsruhe, INFRAS.

Krugman P. (1998), The Role of Geography in Development, Paper prepared for the Annual World Bank Conference on Development Economics, Washington D.C.

Mathew T. V., Krishna Rao K. V. (2006), Introduction to Transportation Engineering, Bombay, National Programme on Technology Enhanced Learning.

MSCI (2014a), About MSCI, http://www.msci.com/about (dostęp: 28.08.2014).

MSCI (2014b), MSCI Emerging Markets Indexes, http://www.msci.com/products/indexes/country_ and_regional/em/\# (dostęp: 28.08.2014). 
Rivera V. I., Hernández S. G., Osorno J. A. A., Zaragoza M. L., Ruvalcabra J. I. (2011), Implementing Sustainable Urban Travel Policies in Mexico, International Transport Forum, „Discussion Paper" No. 14.

Rodrigue J.-P., Notteboom T. (2014), The Geography of Transport Systems, Hofstra University, New York, https://people.hofstra.edu/geotrans/eng/ch7en/conc7en/ch7clen.html (dostęp: 28.08.2014).

Roschlau M. W. (1981), Urban Transport in Developing Countries: the Peseros of Mexico City, Master Thesis, The University of British Columbia, http://circle.ubc.ca/handle/2429/22631 (dostęp: 29.10.2014).

Rydzkowski W., Wojewódzka-Król K. (red.) (2007), Transport, Wydawnictwo Naukowe PWN, Warszawa.

Signal B. I. (2010), Towards sustainable urban transport in India, ,Journeys” November, http:// www.lta.gov.sg/ltaacademy/doc/J10Nov-p13Singal_UrbanTransportIndia.pdf (dostęp: 30.10.2014).

Smith A. (1776), An Inquiry into the Nature and Causes of the Wealth of Nations, wersja wznowiona: Metalibri (2007), http://metalibri.incubadora.fapesp.br/portal (dostęp: 20.10.2008).

Taylor G. (2012), NAFTA key to economic, social growth in Mexico, ,The Washington Times Monday", May 14, 2012, http://www.washingtontimes.com/news/2012/may/14/nafta-key-to-economic-social-growth-in-mexico/?page=all\#pagebreak (dostęp: 8.10.2014).

UN (2010), Mexico City's Green Plan, UN Sustainable Development Knowledge Platform, $\mathrm{http} / /$ sustainabledevelopment.un.org/index.php?page=view\&type=99\&nr=206\&menu=1449 (dostęp: 29.10.2014).

Wachs M. (2011), Transportation, jobs, and economic growth, „Access”, No. 38.

WHO (2014), Global Status Report on Road Safety 2013. Supporting a Decade of Action, WHO, Luksemburg.

World Bank (1999), Managing the Social Dimensions of Transport. The Role of Social Assessment, http://www.socialassessment.com/documents/KudatWorks/1999/1999-Managing_Social-Dimensions-of-Transport_Role-of-Social-Assessment-Ayse-Kudat-citations.pdf (dostęp: 28.08.2014).

World Bank (2009), Project appraisal document on a proposed grant from the global environment facility trust fund in the amount of US\$ 5.378 million to the united Mexican states for the sustainable transport and air quality project in support of phase 3 of the sustainable transport and air quality program, Report No. 42880-MX.

World Bank (2014a), Dane statystyczne, http://data.worldbank.org/country/mexico (dostęp: 8.10.2014).

World Bank (2014b), China - Xian Sustainable Urban Transport Project, http://documents.worldbank.org/curated/en/2014/07/19794506/china-xian-sustainable-urban-transport-project-resettlement-action-plan-vol-14-14-resettlement-due-diligence-report-xinzhu-bus-depot-subcomponent (dostęp: 30.10.2014).

World Bank (2014c), Sustainable Transport and Air Quality, http://www.worldbank.org/projects/ P114012/sustainable-transport-air-quality?lang=en (dostęp: 30.10.2014). 


\title{
Monika Paradowska
}

\section{SUSTAINABLE URBAN TRANSPORT POLICY IN EMERGING COUNTRIES - CASE STUDY OF MEXICO}

\begin{abstract}
Negative external effects of transport are a huge problem of contemporary cities because of adverse effects on socio-economic development. These processes are visible not only in high or medium developed countries, but also in high populated, big metropolises in so called emerging countries, such as China, India, Brazil or Mexico. This paper is aimed at presenting the selected aspects of sustainable urban transport policy in the capital of one of these countries - Mexico - as well as at describing the specificity of creating instruments for sustainable transport resulting from various conditions. There are different sources used in the paper regarding sustainable transport in Mexico, including reports and statistical data of the World Bank.
\end{abstract}

Keywords: negative effects of transport, sustainable urban transport policy, Mexico. 